Buletin Ilmiah Mat. Stat. dan Terapannya (Bimaster)

Volume 09, No. 1 (2020), hal 129 - 136.

\title{
PEMODELAN DATA RUNTUN WAKTU DENGAN ARIMAX
}

\author{
Nurfitri, Yundari, Shantika Martha
}

\begin{abstract}
INTISARI
Model Autoregressive Integrated Moving Average Exogenous (ARIMAX) merupakan salah satu perluasan dari model ARIMA dengan penambahan variabel exogenous. Dalam penelitian ini, model ARIMAX digunakan untuk pemodelan data harga saham PT. Astra Agro Lestari Tbk (AALI) terhadap data kurs USD bulanan dari tahun 2010 sampai dengan 2018 dengan kurs USD sebagai variabel exogenous dengan tujuan untuk mengestimasi parameter model ARIMAX. Langkah awal dilakukan uji kestasioneran data. Dari hasil uji kestasioneran data diperoleh hasil bahwa data tidak stasioner sehingga dilakukan proses diferensiasi satu kali pada masing-masing data. Selanjutnya identifikasi model ARIMA, estimasi parameter model ARIMA menggunakan metode kuadrat terkecil, uji diagnostik pada model ARIMA dan pemilihan model ARIMA terbaik berdasarkan pada nilai probabilitas atau p-value yang signifikan, adjusted $r$-squared yang lebih besar serta nilai akaike's information criterion (AIC) dan schwarz criterion (SC) yang terkecil. Tahapan selanjutnya ialah penambahan variabel exogenous ke dalam model ARIMA sehingga diperoleh model ARIMAX. Estimasi parameter model ARIMAX dengan menggunakan metode kuadrat terkecil (least square). Setelah mengestimasi parameter maka dilakukan uji diagnostik pada model ARIMAX dengan menggunakan uji Q-Ljung-Box sehingga diperoleh bahwa harga saham AALI dipengaruhi oleh harga saham itu sendiri sedangkan kurs USD tidak signifikan pada model ARIMAX sehingga menunjukkan bahwa kurs USD tidak berpengaruh signifikan terhadap harga saham AALI.
\end{abstract}

Kata Kunci : Saham, Kurs USD, Akaikes's Information Criterion (AIC).

\section{PENDAHULUAN}

Analisis runtun waktu merupakan analisis sekumpulan data dalam suatu periode waktu yang lampau yang berguna untuk mengetahui atau meramalkan kondisi masa mendatang. Hal ini didasarkan pada perilaku manusia yang banyak dipengaruhi oleh kondisi atau waktu sebelumnya sehingga dalam hal ini faktor waktu sangat penting peranannya [1]. Metode runtun waktu yang digunakan untuk peramalan data runtun waktu adalah autoregressive (AR), moving average (MA), autoregressive moving average (ARMA) dan autoregressive integrated moving average (ARIMA). Penerapan modelmodel tersebut digunakan pada kajian terhadap data univariat. Pada model AR yaitu data periode sekarang dipengaruhi oleh data periode sebelumnya. Model MA yaitu data periode sekarang dipengaruhi oleh nilai residual data sebelumnya. Model ARIMA ialah gabungan dari model AR dan MA yang menggunakan proses diferensiasi [2].

Pada analisis runtun waktu tertentu, variabel dependen $Z_{t}$ tidak hanya dipengaruhi oleh data sebelumnya, tetapi juga dipengaruhi oleh variabel independen lainnya yang disebut sebagai variabel exogenous. Model ARIMA dengan penambahan variabel exogenous disebut dengan model autoregressive integrated moving average exogenous (ARIMAX) [3]. Dalam penelitian ini, model ARIMAX digunakan untuk pemodelan data harga saham PT. Astra Agro Lestari Tbk (AALI) terhadap data kurs USD bulanan dari tahun 2010 sampai dengan 2018 dengan kurs USD sebagai variabel exogenous. Saham merupakan tanda penyertaan atau kepemilikan seseorang dalam suatu perusahaan [4]. Selembar saham ialah selembar kertas yang menerangkan bahwa pemilik kertas adalah pemilik saham dari suatu perusahaan yang menerbitkan kertas (saham) tersebut. Faktor yang mempengaruhi 
naik turunnya harga saham di Bursa Efek Indonesia (BEI) pada suatu perusahaan salah satunya ialah kurs mata uang. Kurs (exchange rate) atau nilai tukar mata uang adalah pertukaran antara dua mata uang yang berbeda, yaitu merupakan perbandingan nilai atau harga antara kedua mata uang tersebut [4]. Tujuan penelitian ini ialah mengestimasi parameter model ARIMAX pada data harga saham AALI dan kurs USD dengan data yang digunakan adalah data bulanan dari tahun 2010 sampai dengan 2018. Data yang digunakan merupakan data runtun waktu yang bersifat tidak musiman dengan satu variabel exogenous yaitu kurs USD.

\section{MODEL AUTOREGRESSIVE INTEGRATED MOVING AVERAGE (ARIMA)}

Model ARMA merupakan kombinasi dari model AR(p) dan MA(q) Bentuk umum model $\operatorname{ARMA}(p, q)$ adalah sebagai berikut:

$$
\mathrm{Z}_{\mathrm{t}}=\phi_{1} \mathrm{Z}_{\mathrm{t}-1}+\ldots+\phi_{\mathrm{p}} \mathrm{Z}_{\mathrm{t}-\mathrm{p}}+\varepsilon_{\mathrm{t}}-\theta_{1} \varepsilon_{\mathrm{t}-1-1}-\ldots-\theta_{\mathrm{q}} \varepsilon_{\mathrm{t}-\mathrm{q}}
$$

Dengan $Z_{t}$ adalah data pada waktu ke- $t, Z_{t-1}, \ldots, Z_{t-p}$ adalah data pada $p$ periode sebelumnya, $\phi_{1}, \ldots, \phi_{p}$ adalah parameter $\mathrm{AR}, \varepsilon_{\mathrm{t}-1}, \ldots, \varepsilon_{\mathrm{t}-\mathrm{q}}$ adalah nilai residual pada $\mathrm{q}$ periode sebelumnya, $\theta_{1}, \ldots, \theta_{\mathrm{q}}$ adalah parameter MA dan $\varepsilon_{\mathrm{t}}$ adalah nilai residual pada waktu $\mathrm{t}$

Data yang ditemui sering kali tidak stasioner, apabila data yang digunakan tidak stasioner maka diperlukan proses diferensiasi sehingga model yang digunakan ialah model ARMA dengan proses diferensiasi atau biasa disebut dengan model ARIMA. Bentuk umum dari model ARIMA(p,d,q) ialah:

$$
\phi(B)(1-B){ }^{d} Z_{t}=\mu^{\prime}+\theta(B) \varepsilon_{t}
$$

dengan $\phi(B)=1-\phi_{1} B-\phi_{2} B^{2}-\ldots-\phi_{p} B^{p}$ dan $\theta(B)=1-\theta_{1} B-\theta_{2} B^{2}-\ldots-\theta_{q} B^{q}$

Berdasarkan persamaan (1) maka persamaan model ARIMA(1,1,1) adalah:

$$
\begin{aligned}
& \left(1-\phi_{1} B\right)(1-B) Z_{t}=\mu^{\prime}+\theta(B) \varepsilon_{t} \\
& \left(1-B-\phi_{1} B+\phi_{1} B^{2}\right) Z_{t}=\mu^{\prime}+\left(1-\theta_{1} B\right) \varepsilon_{t} \\
& Z_{t}=\mu^{\prime}+B Z_{t}+\phi_{1} B Z_{t}-\phi_{1} B^{2} Z_{t}+\varepsilon_{t}-\theta_{1} B \varepsilon_{t} \\
& Z_{t}=\mu^{\prime}+\left(1+\phi_{1}\right) B Z_{t-1}-\phi_{1} Z_{t-2}+\varepsilon_{t}-\theta_{1} \varepsilon_{t-1}
\end{aligned}
$$

dimana

$\mu \quad$ : suatu konstanta,

$\mathrm{Z}_{\mathrm{t}-1}, \mathrm{Z}_{\mathrm{t}-2}$ : nilai pengamatan pada periode ke $t-1, t-2$,

$\varepsilon_{\mathrm{t}}, \varepsilon_{\mathrm{t}-1}:$ nilai error pada periode ke $t, t-1$,

$\phi_{1} \quad$ : parameter $\operatorname{AR}(1)$,

$\theta_{1} \quad$ : parameter $\mathrm{MA}(1)$

\section{MODEL AUTOREGRESSIVE INTEGRATED MOVING AVERAGE EXOGENOUS (ARIMAX)}

Model ARIMAX adalah model ARIMA yang menggunakan variabel exogenous. Dalam metode ini, variabel dependen yang biasa dikenal dengan $Z_{t}$ sering kali terpengaruh oleh variabel independen lainnya yaitu $X_{t}$ pada waktu ke-t. Variabel $X_{t}$ tersebut disebut sebagai variabel exogenous. Variabel exogenous adalah variabel independen yang nilainya tidak dipengaruhi oleh variabel lain didalam model. Metode ARIMA dengan penambahan variabel exogenous disebut dengan metode autoregressive integrated moving average exogenous (ARIMAX). Bentuk umum persamaan model $\operatorname{ARIMAX}(\mathrm{p}, \mathrm{d}, \mathrm{q})$ adalah sebagai berikut [5]:

$$
(1-\mathrm{B})^{\mathrm{d}} \phi_{\mathrm{p}}(\mathrm{B}) \mathrm{Z}_{\mathrm{t}}=\theta_{\mathrm{q}}(\mathrm{B}) \varepsilon_{\mathrm{t}}+\gamma_{1} \mathrm{X}_{1, \mathrm{t}}+\ldots+\gamma_{\mathrm{r}} \mathrm{X}_{\mathrm{r}, \mathrm{t}}
$$

dengan $\mathrm{B}$ adalah operator backshif, $\mathrm{X}_{\mathrm{r}, \mathrm{t}}$ adalah variabel eksogen, $\phi_{\mathrm{p}}(\mathrm{B})$ adalah komponen autoregressive dan $\theta_{\mathrm{q}}(\mathrm{B})$ adalah komponen moving average. 


\section{STUDI KASUS}

Data yang digunakan dalam penelitian ini merupakan data sekunder, yaitu data harga saham PT. Astra Agro Lestari Tbk (AALI) sebagai variabel dependen dan data kurs USD sebagai variabel exogenous dengan jumlah masing-masing data sebanyak $n=108$ [6]. Data tersebut merupakan data bulanan dari Januari 2010 sampai dengan Desember 2018. Diketahui bahwa $Z_{t}$ adalah data harga saham dan $X_{t}$ merupakan kurs USD. PT. Astra Agro Lestari Tbk (Perseroan) yang merupakan penggabungan dari beberapa perusahaan yang bergerak dalam bidang perkebunan yang bermarkas di Jakarta. Perusahaan mulai mengembangkan industri perkebunan di Indonesia sejak lebih dari 30 tahun yang lalu. Berawal dari perkebunan ubi kayu, kemudian mengembangkan tanaman karet, hingga pada tahun 1984, dimulailah budidaya tanaman kelapa sawit di Provinsi Riau. Kini, perusahaan terus berkembang dan menjadi salah satu perusahaan perkebunan kelapa sawit terbesar dan dikelola melalui manajemen yang baik. Faktor yang mempengaruhi naik turunnya harga saham di Bursa Efek Indonesia (BEI) pada suatu perusahaan salah satunya ialah kurs mata uang. Kurs (exchange rate) atau nilai tukar mata uang adalah pertukaran antara dua mata uang yang berbeda, yaitu merupakan perbandingan nilai atau harga antara kedua mata uang tersebut.

Plot data harga saham AALI dan kurs USD dari Januari 2010 sampai dengan Desember 2018 disajikan pada Gambar 1.

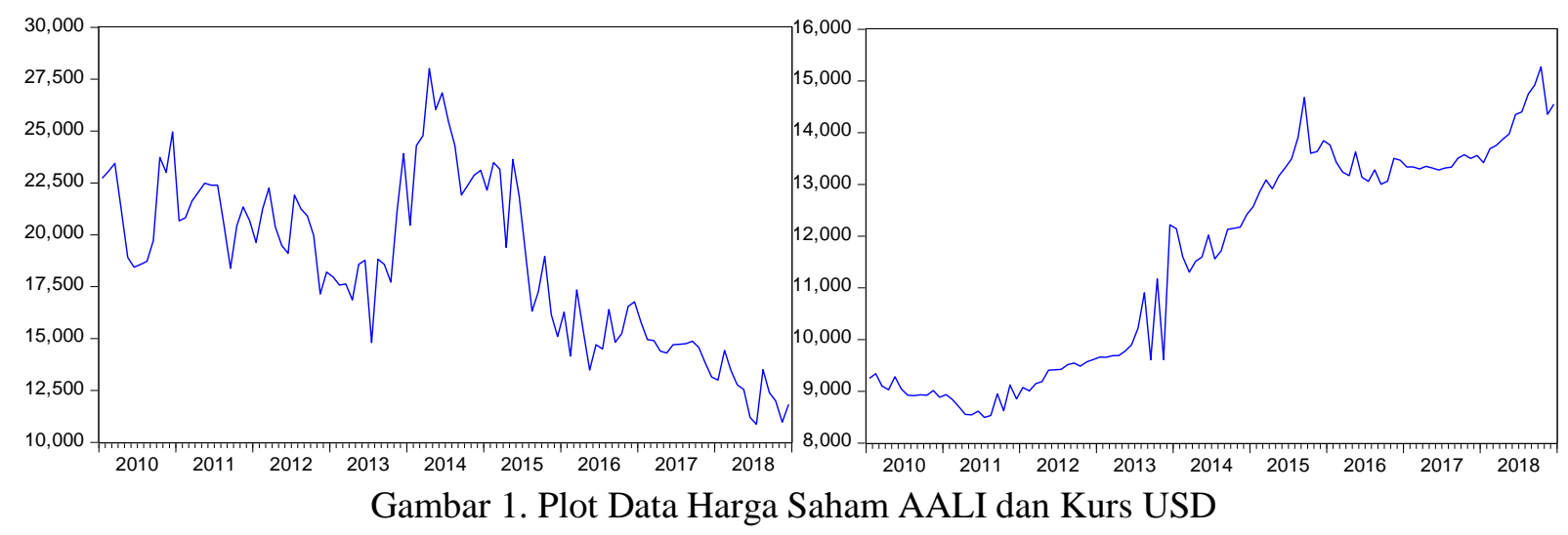

Berdasarkan plot pada Gambar 1 menunjukkan bahwa data mengandung trend sehingga dapat dikatakan bahwa data tidak stasioner dalam varian dan rata-rata. Untuk meyakinkan lagi dapat dilakukan uji akar unit (ADF) dengan melihat apakah terdapat unit root didalam model atau tidak. Pengujian dilakukan dengan menguji hipotesis $\mathrm{H}_{0}: \rho=0$ (terdapat unit root) dalam persamaan regresi:

$$
\Delta \mathrm{Z}_{\mathrm{t}}=\alpha+\delta \mathrm{t}+\rho \mathrm{Z}_{\mathrm{t}-1}+\sum_{\mathrm{j}=1}^{\mathrm{k}} \phi_{\mathrm{j}} \Delta \mathrm{Z}_{\mathrm{t}-\mathrm{j}}+\mathrm{e}_{\mathrm{t}}
$$

dengan $\Delta \mathrm{Z}_{\mathrm{t}}=\mathrm{Z}_{\mathrm{t}}-\mathrm{Z}_{\mathrm{t}-1}$ dan $\rho=\mathrm{a}-1$, dengan a adalah koefisien model Dickey Fuller.

Hipotesis nol ditolak jika nilai statistik uji ADF memiliki nilai kurang (lebih negatif) dibandingkan nilai daerah kritik yang ditampilkan oleh eviews. Jika hipotesis nol ditolak maka data stasioner. Hasil uji ADF pada data AALI dan kurs USD disajikan pada Tabel 1.

Tabel 1 Hasil Uji ADF Pada Data Harga Saham AALI dan Kurs USD

\begin{tabular}{|c|c|c|c|c|}
\hline \multirow{2}{*}{ Variabel } & \multirow{2}{*}{ ADF Statistic } & Nilai Kritis & \multirow{2}{*}{$p$-value } & \multirow{2}{*}{ Kesimpulan } \\
\hline & & $5 \%$ & & \\
\hline AALI & $-1,259404$ & $-2,889200$ & 0,6461 & Tidak Stasioner \\
\hline Kurs USD & $-0,210848$ & $-2,888932$ & 0,9326 & Tidak Stasioner \\
\hline
\end{tabular}


Berdasarkan Tabel 1 hasil uji ADF yang diperoleh yaitu nilai satistik uji ADF dari variabel AALI dan kurs USD masing-masing sebesar -1,259404 dan -0,210848. Nilai daerah kritis 5\% yang diperoleh masing-masing variabel ialah sebesar -2,889200 dan -2,888932. Diperoleh nilai statistik uji ADF dari variabel AALI dan kurs USD lebih dari nilai daerah kritis 5\% disimpulkan terima $H_{0}$ yang berarti variabel AALI dan kurs USD tidak stasioner. Oleh karena itu, dilakukan proses diferensiasi satu kali untuk memperoleh data yang stasioner. Hasil uji ADF pada data DAALI dan DUSD disajikan pada Tabel 2.

Tabel 2 Hasil Uji ADF Pada Diferensiasi Pertama

\begin{tabular}{|c|c|c|c|c|}
\hline Variabel & ADF Statistic & $\begin{array}{c}\text { Nilai Kritis } \\
5 \%\end{array}$ & $p$-value & Kesimpulan \\
\hline DAALI & $-9,408484$ & $-2,889200$ & 0,0000 & Stasioner \\
\hline DUSD & $-18,54904$ & $-2,888932$ & 0,0000 & Stasioner \\
\hline
\end{tabular}

Berdasarkan Tabel 2 terlihat bahwa data DAALI dan DUSD telah stasioner pada proses diferensiasi orde pertama dengan nilai statistik uji ADF < nilai kritis 5\% serta nilai p-value $<5 \%$. Jadi tolak $H_{0}$ yang berarti data telah stasioner dalam mean dan varian. Langkah selanjutnya yaitu identifikasi model ARIMA untuk menentukan $p, q$ sementara yang dapat dilihat melalui correlogram ACF dan PACF. Correlogram data harga saham AALI hasil diferensiasi satu kali disajikan pada Gambar 2.

\begin{tabular}{|c|c|c|c|c|c|c|c|c|}
\hline Autocorr & relation & Partial Co & rrelation & & AC & PAC & a-stat & Prob \\
\hline$\square$ & 1 & $\square$ & I & 1 & -0.246 & -0.246 & 6.6452 & 0.010 \\
\hline 18 & I & 1 & I & 2 & -0.093 & -0.163 & 7.6050 & 0.022 \\
\hline & I & 1 & I & 3 & 0.025 & -0.045 & 7.6764 & 0.053 \\
\hline & I & I & I & 4 & 0.026 & 0.006 & 7.7530 & 0.101 \\
\hline I & 1 & 1 & 1 & 5 & -0.022 & -0.014 & 7.8084 & 0.167 \\
\hline I & I & 1 & I & 6 & -0.044 & -0.052 & 8.0309 & 0.236 \\
\hline I & I & 1 & I & 7 & -0.007 & -0.042 & 8.0367 & 0.329 \\
\hline & י י & $1=$ & ו ב & 8 & 0.132 & 0.117 & 10.105 & 0.258 \\
\hline 든 & I & 10 & I & 9 & -0.162 & -0.108 & 13.243 & 0.152 \\
\hline & י י & & 1 & 10 & 0.102 & 0.069 & 14.502 & 0.151 \\
\hline I & I & I & I & 11 & -0.018 & -0.010 & 14.543 & 0.204 \\
\hline I & I & 口 & I & 12 & -0.150 & -0.162 & 17.319 & 0.138 \\
\hline 1 & 1 & 13 & 1 & 13 & 0.008 & -0.078 & 17.327 & 0.185 \\
\hline I & 1 & 11 & I & 14 & 0.044 & -0.012 & 17.568 & 0.227 \\
\hline & יפ & I & 马 & 15 & 0.154 & 0.176 & 20.581 & 0.151 \\
\hline C & I & 1연 & I & 16 & -0.187 & -0.120 & 25.042 & 0.069 \\
\hline 1 & I & 17 & I & 17 & -0.013 & -0.036 & 25.065 & 0.093 \\
\hline I & 1 & 1 工 & I & 18 & 0.028 & -0.084 & 25.165 & 0.120 \\
\hline & I & 10 & I & 19 & -0.047 & -0.064 & 25.464 & 0.146 \\
\hline 1 & I & 1 & I & 20 & -0.134 & -0.156 & 27.865 & 0.113 \\
\hline 1 & 马 & $1=$ & נ & 21 & 0.188 & 0.106 & 32.640 & 0.050 \\
\hline I & I & 1 & 1 & 22 & -0.039 & 0.007 & 32.844 & 0.064 \\
\hline I & I & 1 工 & I & 23 & -0.051 & -0.094 & 33.209 & 0.077 \\
\hline I & I & 10 & I & 24 & -0.031 & -0.044 & 33.347 & 0.097 \\
\hline I & I & I & I & 25 & 0.084 & -0.021 & 34.350 & 0.101 \\
\hline 10 & I & I & 1 & 26 & -0.080 & -0.044 & 35.271 & 0.106 \\
\hline$\square$ & I & $\square$ & I & 27 & -0.209 & -0.248 & 41.656 & 0.036 \\
\hline 1 & י י כ & 1 & I & 28 & 0.162 & 0.038 & 45.522 & 0.020 \\
\hline & 曰 & I & I & 29 & 0.102 & 0.007 & 47.065 & 0.018 \\
\hline 10 & I & 1 & I & 30 & -0.071 & -0.011 & 47.828 & 0.021 \\
\hline 1 & I & I & I & 31 & 0.012 & 0.015 & 47.851 & 0.027 \\
\hline I & I & 1 & I & 32 & 0.035 & -0.014 & 48.037 & 0.034 \\
\hline I & I & 1 & I & 33 & -0.014 & -0.004 & 48.068 & 0.044 \\
\hline & I & I & I & 34 & 0.043 & 0.057 & 48.369 & 0.052 \\
\hline 10 & 1 & I & I & 35 & -0.025 & 0.049 & 48.467 & 0.065 \\
\hline , & י י & 1 & I & 36 & 0.119 & -0.012 & 50.792 & 0.052 \\
\hline
\end{tabular}

Gambar 2. Correlogram Data Hasil Diferensiasi Pertama

Berdasarkan correlogram pada Gambar 2, terlihat bahwa ACF dan PACF pada lag pertama berada di luar garis Bartlett maka kemungkinan pertama $\mathrm{p}=1, \mathrm{q}=0$ atau kemungkinan kedua $\mathrm{p}=0, \mathrm{q}=1$ sehingga diperoleh model awal ARIMA untuk data harga saham AALI adalah ARIMA(1,1,1) $\operatorname{ARIMA}(1,1,0)$ dan ARIMA $(0,1,1)$.

Hasil estimasi model $\operatorname{ARIMA}(1,1,1), \operatorname{ARIMA}(1,1,0)$ dan $\operatorname{ARIMA}(0,1,1)$ dapat dilihat pada Tabel 3 
Tabel 3 Estimasi Model ARIMA Pada Data AALI

\begin{tabular}{ccccccc}
\hline Model & Variabel & koefisien & Prob. & $\begin{array}{c}\text { Ajusted } R \text { - } \\
\text { Squared }\end{array}$ & SC & AIC \\
\hline \multirow{2}{*}{ ARIMA(1,1,1) } & AR(1) & 0,279302 & 0,2865 & & & \\
& MA(1) & $-0,572140$ & 0,0110 & & 1778816 & 1771278 \\
ARIMA $(1,1,0)$ & AR(1) & $-0,246479$ & 0,0110 & 0,051580 & 1777187 & 1772162 \\
ARIMA(0,1,1) & MA(1) & $-0,322144$ & 0,0007 & $\mathbf{0 , 0 7 1 6 0 5}$ & $\mathbf{1 7 7 4 1 1 9}$ & $\mathbf{1 7 6 9 1 2 3}$ \\
\hline
\end{tabular}

Berdasarkan Tabel 3 diperoleh model ARIMA $(0,1,1)$ memiliki nilai Adjusted $R$-Squared yang lebih besar serta nilai AIC dan SC yang terkecil. Tahapan selanjutnya ialah pemeriksaan diagnostik pada model ARIMA $(0,1,1)$ dengan melakukan uji $Q$-Ljung_Box dan plot ACF/PACF untuk melihat apakah ada korelasi serial dalam residual dari hasil estimasi dengan model yang diamati. Hasil uji $Q$-LjungBox pada masing-masing model diperoleh nilai ACF/PACF tidak signifikan pada semua model yang ditandai dengan nilai p-value atau prob dari statistik $Q$-Ljung-Box $>\alpha=5 \%$ sehingga disimpulkan bahawa residual dari model ARIMA bersifat white noise dan tidak terdapat korelasi serial dalam residual dari model ARIMA. Dengan demikian dapat disimpulkan bahwa model $\operatorname{ARIMA}(0,1,1)$ merupakan model yang sesuai untuk menggambarkan sifat-sifat data AALI. Hasil uji diagnostik disajikan pada Gambar 3.

\begin{tabular}{|c|c|c|c|c|c|c|}
\hline Autocorrelation & Partial Correlation & & $A C$ & PAC & Q-Stat & Prob \\
\hline & & 1 & 0.025 & 0.025 & 0.0708 & \\
\hline & ic & 2 & -0.081 & -0.082 & 0.8057 & 0.369 \\
\hline 1 & 17 & 3 & 0.007 & 0.011 & 0.8112 & 0.667 \\
\hline 1 & ' & 4 & 0.019 & 0.012 & 0.8516 & 0.837 \\
\hline 1 & 15 & 5 & -0.033 & -0.032 & 0.9727 & 0.914 \\
\hline & ' & 6 & -0.050 & -0.046 & 1.2648 & 0.939 \\
\hline & 14 & 7 & 0.008 & 0.005 & 1.2722 & 0.973 \\
\hline ין י & 1 & 8 & 0.099 & 0.092 & 2.4228 & 0.933 \\
\hline 15 & 區 & 9 & -0.116 & -0.120 & 4.0113 & 0.856 \\
\hline & 1 . & 10 & 0.052 & 0.077 & 4.3362 & 0.888 \\
\hline & 1 & 11 & -0.053 & -0.084 & 4.6760 & 0.912 \\
\hline & 号 & 12 & -0.169 & -0.162 & 8.1927 & 0.696 \\
\hline 17 & 1 & 13 & -0.019 & -0.008 & 8.2398 & 0.766 \\
\hline 1 ' & 1 & 14 & 0.074 & 0.052 & 8.9327 & 0.778 \\
\hline ים י & יב & 15 & 0.125 & 0.122 & 10.910 & 0.693 \\
\hline 1 & i & 16 & -0.167 & -0.184 & 14.484 & 0.489 \\
\hline 1 & 17 & 17 & -0.067 & -0.030 & 15.063 & 0.520 \\
\hline 1 & 1 & 18 & -0.017 & -0.094 & 15.101 & 0.588 \\
\hline it & 15 & 19 & -0.085 & -0.067 & 16.059 & 0.588 \\
\hline 10 & 1 & 20 & -0.114 & -0.092 & 17.793 & 0.536 \\
\hline ישל' & ישל י & 21 & 0.148 & 0.137 & 20.753 & 0.412 \\
\hline & 151 & 22 & -0.014 & -0.060 & 20.780 & 0.472 \\
\hline 1 & id & 23 & -0.066 & -0.105 & 21.379 & 0.497 \\
\hline & 17 & 24 & -0.040 & -0.026 & 21.604 & 0.544 \\
\hline & 1 & 25 & 0.033 & -0.039 & 21.759 & 0.594 \\
\hline 15 & ' 1 & 26 & -0.129 & -0.100 & 24.164 & 0.510 \\
\hline 면 & . & 27 & -0.203 & -0.200 & 30.199 & 0.259 \\
\hline יש & יבי & 28 & 0.139 & 0.115 & 33.066 & 0.195 \\
\hline ין & 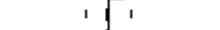 & 29 & 0.131 & -0.008 & 35.651 & 0.152 \\
\hline 1 & 1 & 30 & -0.027 & -0.008 & 35.758 & 0.181 \\
\hline 111 & 1 & 31 & 0.016 & 0.014 & 35.800 & 0.215 \\
\hline b 1 & 1 & 32 & 0.045 & -0.010 & 36.108 & 0.242 \\
\hline 11 & 1 & 33 & 0.015 & 0.023 & 36.145 & 0.281 \\
\hline 1 1 & $1 \mathrm{~b}$ & 34 & 0.051 & 0.062 & 36.559 & 0.307 \\
\hline 111 & 1 & 35 & 0.020 & 0.018 & 36.623 & 0.348 \\
\hline י & 14 & 36 & 0.096 & -0.044 & 38.137 & 0.329 \\
\hline
\end{tabular}

Gambar 3. Plot ACF/PACF Hasil Uji Diagnostik Q-Ljung-Box

Tahapan selanjutnya yaitu menambahkan variabel exogenous ke dalam model $\operatorname{ARIMA}(0,1,1)$ sehingga diperoleh model ARIMAX $(0,1,1)$. Estimasi model $\operatorname{ARIMAX}(0,1,1)$ disajikan pada Tabel 4.

Tabel 4 Estimasi Model ARIMAX $(0,1,1)$

\begin{tabular}{lccccc}
\hline \multicolumn{1}{c}{ Variabel } & Koefisien & Prob. & $\begin{array}{c}\text { Adjusted } \\
\text {-Squared }\end{array}$ & SC & AIC \\
\hline ARIMA $(0,1,1)$ & $-0,309981$ & 0,0012 & 0,065602 & 17,74763 & 17,69767 \\
DUSD & $-0,191034$ & $\mathbf{0 , 6 4 2 3}$ & & & \\
\hline
\end{tabular}


Hasil estimasi model $\operatorname{ARIMAX}(0,1,1)$ diperoleh nilai parameter yaitu $\theta_{1}=-0,309981$ dengan nilai parameter $\mathrm{MA}(1)$ diperoleh nilai Prob. $0,0012<0,05$, maka $\mathrm{H}_{0}$ diterima yang berarti MA signifikan dalam model $\operatorname{ARIMAX}(0,1,1)$ dan nilai parameter $\gamma_{1}=-0,191034$ dengan nilai Prob. 0,6423>0,05 maka H0 ditolak yang berarti bahwa kurs USD tidak signifikan dalam model ARIMAX $(0,1,1)$. Nilai estimasi parameter untuk model $\operatorname{ARIMAX}(0,1,1)$ yang diperoleh dirangkum ke dalam Tabel 5:

Tabel 5 Hasil Estimasi Parameter dari Model ARIMAX $(0,1,1)$

\begin{tabular}{|c|l|l|l|}
\hline & ARIMAX $(0,1,1)$ & Prob. & Keterangan \\
\hline$\theta_{1}$ & $-0,309981$ & 0,0012 & Signifikan \\
\hline$\gamma_{1}$ & $-0,191034$ & 0,6423 & Tidak Signifikan \\
\hline
\end{tabular}

Model ARIMAX $(0,1,1)$ ialah sebagai berikut:

$$
\begin{gathered}
\hat{Z}_{\mathrm{t}}=\mathrm{Z}_{\mathrm{t}-1}-\theta_{1} \varepsilon_{\mathrm{t}-1}+\gamma_{1}\left(\mathrm{X}_{1, \mathrm{t}}-\mathrm{X}_{1, \mathrm{t}-1}\right) \\
\hat{Z}_{\mathrm{t}}=\mathrm{Z}_{\mathrm{t}-1}+0,309981 \varepsilon_{\mathrm{t}-1}-0,191034\left(\mathrm{X}_{1, \mathrm{t}}-\mathrm{X}_{1, \mathrm{t}-1}\right) \\
\hat{Z}_{\mathrm{t}}=\mathrm{Z}_{\mathrm{t}-1}+0,309981 \varepsilon_{\mathrm{t}-1}-0,191034 \mathrm{X}_{1, \mathrm{t}}+0,191034 \mathrm{X}_{1, \mathrm{t}-1}
\end{gathered}
$$

Pada persamaan (3) terlihat bahwa koefisien regresi pada variabel $\varepsilon_{t-1}$ bertanda positif yang berarti hubungan antara harga saham suatu perusahaan pada bulan sekarang sebanding dengan nilai error pada satu bulan sebelumnya. Maka, semakin besar error harga saham sebelumnya maka harga saham bulan sekarang semakin meningkat sebanyak 0,309981 satu satuan. Koefisien regresi pada variabel $\mathrm{X}_{1, \mathrm{t}}$ bertanda negatif yang berarti semakin besar kurs USD saat ini maka harga saham saat ini akan semakin menurun sebanyak 0,191034 satu satuan, sedangkan koefisien regresi pada variabel $X_{1, t-1}$ bertanda positif yang berarti semakin besar kurs USD sebelumnya maka harga saham bulan sekarang akan semakin meningkat sebanyak 0,191034 satu satuan.

\section{Uji Diagnostik Pada Model ARIMAX}

Uji diagnostik pada model ARIMAX $(0,1,1)$ dilakukan dengan uji $Q$-Ljung-Box dan plot ACF dan PACF untuk melihat apakah ada korelasi serial dalam residual dari hasil estimasi dengan model yang diamati. Hasil uji $Q$-Ljung-Box pada model ARIMAX diperoleh nilai ACF/PACF tidak signifikan, yang ditandai dengan nilai $p$-value atau prob dari statistik $Q$-Ljung-Box yang lebih besar dari $\alpha=5 \%$. Sehingga disimpulkan residual dari model $\operatorname{ARIMAX}(0,1,1)$ bersifat white noise dan tidak terdapat korelasi serial dalam residual dari model $\operatorname{ARIMAX}(0,1,1)$. Dengan demikian dapat disimpulkan model

\begin{tabular}{|c|c|c|c|c|c|}
\hline Autocorrelation & Partial Correlation & $\mathrm{AC}$ & PAC & Q-Stat & $\begin{array}{l}\text { Prob } \\
\end{array}$ \\
\hline 活 & 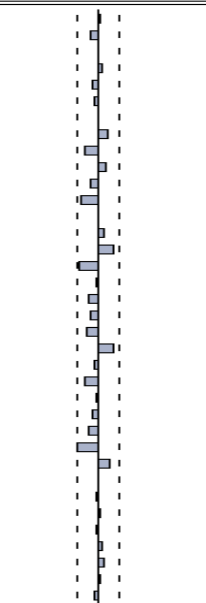 & $\begin{array}{lll} \\
\text { TI }\end{array}$ & 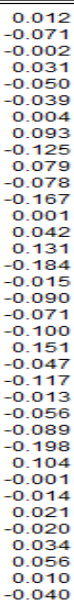 & 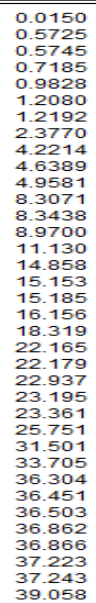 & 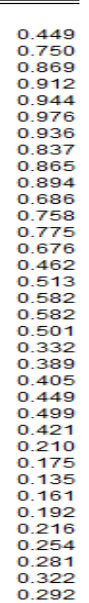 \\
\hline
\end{tabular}
$\operatorname{ARIMAX}(0,1,1)$ merupakan model yang sesuai untuk menggambarkan sifat-sifat data AALI. Hasil uji diagnostik disajikan pada Gambar 4.

Gambar 4. Plot ACF dan PACF Pada Hasil Uji Diagnostik Q-Ljung-Box 
data saham dari data asli dan estimasi dengan menggunakan model $\operatorname{ARIMAX}(0,1,1)$ dapat dilihat melalui Gambar 5:

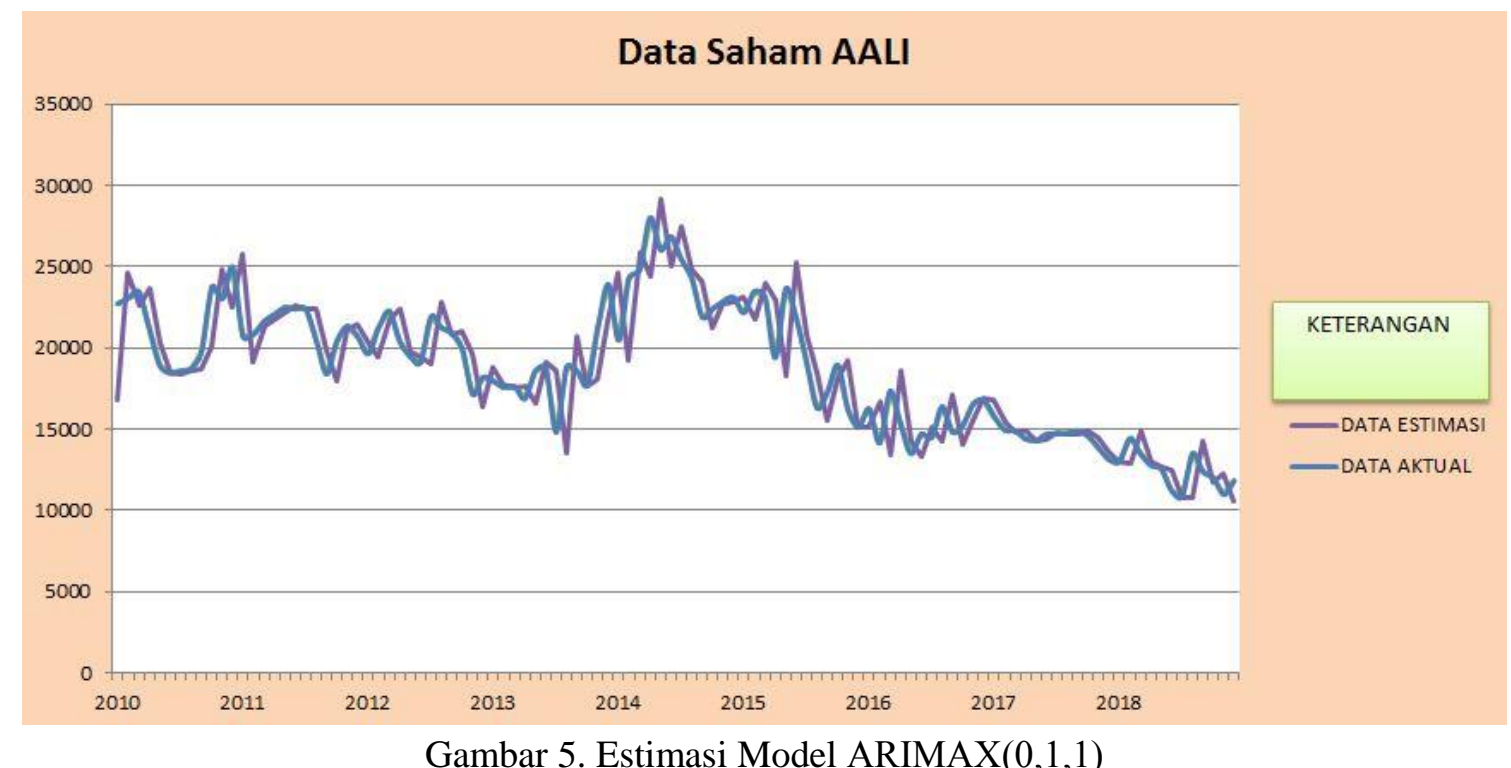

Berdasarkan Gambar 5 terlihat bahwa pola pergerakan harga saham estimasi saham Januari 2018 sampai dengan Desember 2018 menggunakan ARIMAX $(0,1,1)$ mengikuti harga saham sebenarnya. Dari hasil estimasi diperoleh nilai Mean Absolute Persent Error (MAPE) sebesar 7,93\%, sehingga dapat disimpulkan bahwa hasil estimasi data saham AALI menggunakan model $\operatorname{ARIMAX}(0,1,1)$ sudah sangat baik.

Data saham AALI dari Januari 2019 sampai Desember 2019 diprediksi menggunakan model $\operatorname{ARIMAX}(0,1,1)$ disajikan pada Tabel 6:

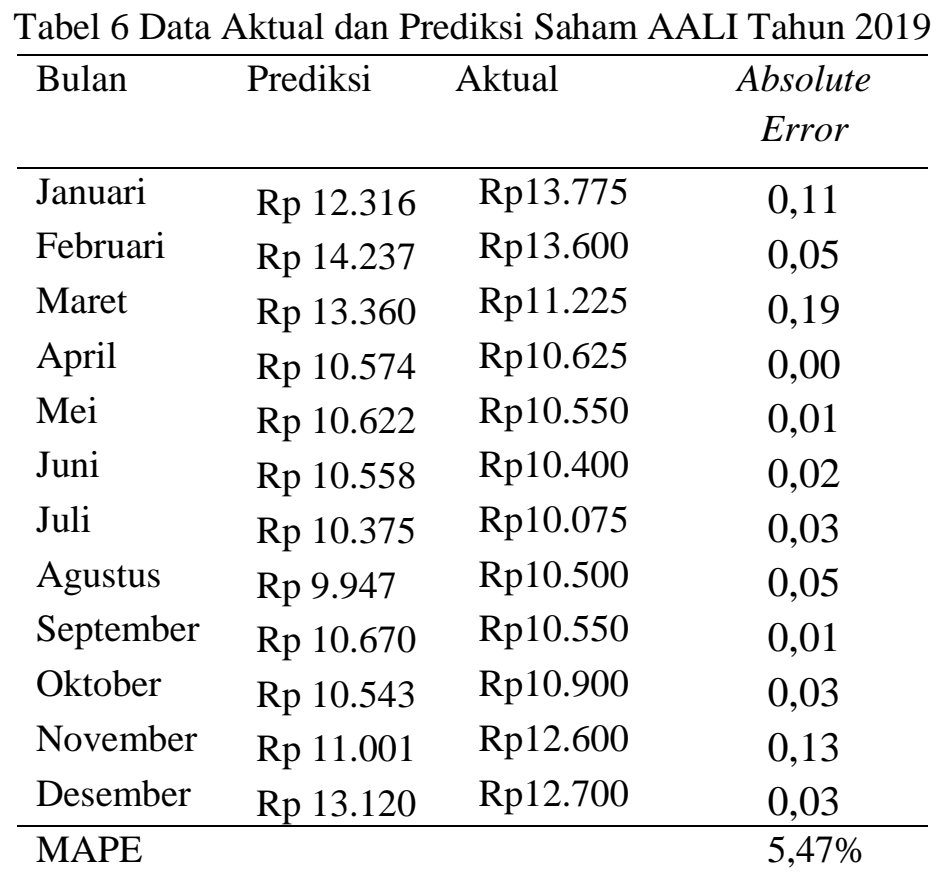

dari hasil prediksi diperoleh nilai Mean Absolute Persent Error (MAPE) sebesar 5,47\% yang merupakan kategori sangat baik. 


\section{PENUTUP}

Berdasarkan hasil analisis dan pembahasan yang telah dijelaskan, maka dapat disimpulkan bahwa estimasi model ARIMAX pada data harga saham AALI dari periode Januari 2010 sampai dengan Desember 2018 diperoleh model terbaik ialah $\operatorname{ARIMAX}(0,1,1)$ yang dipengaruhi oleh nilai parameter yaitu $\theta_{1}=0,309981$ dan $\gamma_{1}=-0,191034$. Hasil estimasi model ARIMAX menunjukkan bahwa variabel yang berpengaruh signifikan terhadap harga saham PT. Astra Agro Lestari Tbk ialah harga saham itu sendiri sedangkan kurs USD tidak signifikan pada model $\operatorname{ARIMAX}(0,1,1)$ sehingga menunjukkan bahwa kurs USD tidak berpengaruh signifikan terhadap harga saham.

\section{DAFTAR PUSTAKA}

[1]. Gujarati, D. and Porter, D. C. Dasar-dasar Ekonometrika. Jakarta: Selemba Empat; 1995.

[2]. Makridakis S, Wheelwright O S, Mogee E V. Metode dan Aplikasi Peramalan. Jakarta: Erlangga; 1999.

[3]. Rosadi, D. Ekonometrika dan Analisis Runtun Waktu Terapan dengan Eviews. Yogyakarta: Andi; 2012.

[4]. Widoatmodjo, S. Cara Sehat Investasi di Pasar Modal: Pengetahuan Dasar. Jakarta: Jurnaliando Aksara Grafika; 2000.

[5]. Cools, M.M., Elke, and Wets. Investigating The Variability in Daily Traffic Counts Using ARIMAX and SARIMA(X). ModelsAssessing Impact of Holidays on Two Divergent Site Locations. Hasselt University, Belgia; 2009.

[6]. Data Historis Saham AALI Astra Agro Lestari Tbk [internet]. 2019 [28 Mei 2019]. https://www.seputarforex.com/saham/data_historis/www.finance.yahoo.com

NURFITRI : :Jurusan Matematika FMIPA Untan, Pontianak fitrimelody@gmail.com

YUNDARI :Jurusan Matematika FMIPA Untan, Pontianak yundari@math.untan.ac.id

SHANTIKA MARTHA :Jurusan Matematika FMIPA Untan, Pontianak shantika.martha@math.untan.ac.id 